\title{
Picea omorika is a self-fertile but outcrossing conifer
}

\author{
HELMI KUITTINEN \& OUTI SAVOLAINEN* \\ Department of Genetics, University of Helsinki, Arkadiankatu 7, SF-00100 Helsinki, Finland and "Department of \\ Genetics, University of Oulu, SF-90570 Oulu, Finland
}

\begin{abstract}
Outcrossing rates were estimated in a natural Yugoslavian and in a cultivated Finnish population of Serbian spruce [Picea omorika (Pančić) Purk.]. The outcrossing rates in the cultivated stand in two years were $0.98 \pm 0.03$ and $1.02 \pm 0.04$, and in the natural stand $0.84 \pm 0.05$. The relative selffertility was estimated in seven trees in the cultivated population. The results indicate high selffertility, which agrees with the earlier information. The high self-fertility combined with high outcrossing rate shows that Serbian spruce, in contrast to most other conifers, employs other means than early acting inbreeding depression to avoid selfing.
\end{abstract}

Keywords: inbreeding depression, mating system, Picea omorika.

\section{Introduction}

Conifer species typically have high outcrossing rates as measured in viable embryos (see Muona, 1989). The probability of self pollination is high in wind-pollinated monoecious conifers, and there is no prezygotic selfincompatibility system but a large share of selfed zygotes die before seed maturation due to homozygosity of embryonic lethals. Thus the early acting inbreeding depression is a substitute for an incompatibility system (see Seavey \& Bawa, 1986).

Serbian spruce [Picea omorika (Pančić) Purk.] is an exceptionally self-fertile conifer (Langner, 1959), and it has been regarded as highly selfing (e.g. Schemske \& Lande, 1985). Serbian spruce has a very narrow range and grows only in an area of less than 60 ha in central Yugoslavia (Burschel, 1965). It has long been thought to lack genetic variability because of its small population size and morphological uniformity (Novák, 1927; Stern \& Roche, 1974, p. 134; Geburek \& Krusche, 1985). These features are consistent with the supposed high selfing. Even if there is no early inbreeding depression, however, inbreeding depression has been found in later life stages (Geburek, 1986). We have earlier shown that despite the claims of uniformity, this species has extensive variability at isozyme loci, and also has genetic variation in seedling characters (Kuittinen et al., 1991). Here we demonstrate that despite its high self-fertility, the species is highly outcrossing. Thus this species differs from most other conifer species in having means other than inbreeding depression to prevent the occurrence of selfed offspring in mature seed.

\section{Materials and methods}

\section{Populations}

Measurements were carried out in populations from Yugoslavia and Finland. The Yugoslavian population, Stolac, is a pure even-aged stand covering about 1.1 ha on the north-facing slope of Mount Veliki Stolac near Višegrad. The other population is cultivated and has been grown for two generations in Finland. It is situated at the Punkaharju Research Station of the Forest Research Institute in Central Finland. It was founded in 1932 with seed from the Mustila arboretum in Elimäki. The Serbian spruce stand in Elimäki was started with seed from a natural population in Bosnia, Yugoslavia. The Punkaharju population consists of about 100 individuals in an area of 0.25 ha.

\section{Breeding system}

Outcrossing rates were estimated with isozyme markers using the maximum likelihood method described by Neale \& Adams (1985). It is based on the mixed mating model (e.g. Brown et al., 1985). Because the census of seed progenies occurs after germination, the estimated outcrossing rates describe the proportion of viable outcrossed seeds among all germinating seeds. 
The marker loci used for the estimation of outcrossing rates were 6-phosphoglugose dehydrogenase, glutamate dehydrogenase, malate dehydrogenase-2, phosphoglugoisomerase-2 and phosphoglugomutase. The electrophoretic methods are described by Kuittinen et al. (1991). In Punkaharju, seeds were collected from 24 trees in 1987, and from 17 trees in 1988. In Stolac seeds from 16 trees were used for estimation. Both the embryo and the megagametophyte were studied from 10 seeds in each tree. In conifers the haploid megagametophyte is genotypically similar to the egg cell and the paternal contribution to a zygote can be derived when the genotypes of both the zygote and the haploid megagametophyte are scored simultaneously.

Wright's (1956) fixation index, $F$, was estimated for each locus as a measure of inbreeding

$\hat{F}=\frac{\hat{h}-\hat{H}}{\hat{h}}$,

where $\hat{h}$ is expected and $\hat{H}$ observed heterozygosity. The statistical significance of the fixation index was tested with $X^{2}=N F^{2}$ (Hedrick, 1987, p. 63).

\section{Crossings}

Selfings and outcrossings were made in seven trees in Punkaharju in May-June of 1988 and 1989. Pollen for outcrosses were taken from five to seven trees so that the volume from any single tree did not exceed onefifth.

Pollen was collected in the same year as the crossings were performed. Twigs carrying abundant male strobili were taken in a warm room to force pollen to mature more rapidly. Before use, the pollen was dried and cleaned by passing it through a filter. Female strobili were isolated in terylene bags before the membrane-covering cone scales were torn, from 4 days to 2 weeks before pollinations. Female flowers were pollinated when receptive, some of them twice. The bags were removed one and a half weeks after pollination.

Mature cones were collected in the middle of September. In addition, wind-pollinated cones were collected from 18 trees in 1988, including those in which crossings were performed. Cones were dried and the seeds were taken out and classified as empty or full by the X-ray method (see Simak, 1980). Those seeds in which the endosperm and embryo were normally developed were classified as full and others were classified as empty. Empty seed percentages were counted for each cone separately.

The genetic validity of pollinations was controlled with isozyme markers.
The relative self-fertility, $R$, was estimated as full seed percentage in self pollination $\left(F_{\mathrm{s}}\right)$ relative to that in cross pollination $\left(F_{c}\right)$ (Sorensen, 1969):

$R=\frac{F_{\mathrm{s}}}{F_{\mathrm{c}}}$

\section{Results}

Outcrossing rates in both years in Punkaharju were high: 0.98 in 1987 and 1.02 in 1988 . These estimates do not differ significantly from 1 . The estimated outcrossing rate in Stolac (0.84) was significantly lower than 1 (Table 1). The average fixation indices at the five enzyme loci in Punkaharju were negative during both years $(-0.016$ and -0.055$)$, but in Stolac the average fixation index was positive (0.110) (Table 1 ). Only a few single locus fixation indices differed significantly from zero.

Many empty seeds were generated in both controlled crosses and wind-pollinated cones in 1988 (Table 2). The average for 71 wind-pollinated cones collected from 18 trees was 88 per cent; empty seed percentages in controlled crosses ranged from 69 to 97 per cent in 1988 and from 33 to 95 per cent in 1989. There were usually large differences between cones within trees and crossings. Overall, our results suggest high self-fertility. Empty seed percentages between selfings and crossings differed significantly in only two trees, 1795 and 5307, in which outcrossing resulted in more sound seeds than selfing. The relative selffertilities ranged from 0.23 to 1.46 , the average being 0.69 . In those trees where crosses were made in 2 years, the values for the 2 years were consistent.

\section{Discussion}

The estimated outcrossing rates in Picea omorika were as high or higher than in other conifer species. Outcrossing rates estimated by the isozyme method are

Table 1 Outcrossing rates $(t)$, their standard deviations, level of significance of test for deviation from 1, and average fixation indices and their standard deviations in polymorphic loci in Punkaharju and Stolac

\begin{tabular}{llllll}
\hline Population & $t$ & $\mathrm{SD}_{t}$ & $P$ & $F$ & $\mathrm{SD}_{\mathrm{F}}$ \\
\hline Punkaharju 1987 & 0.98 & 0.03 & ns & -0.016 & 0.120 \\
Punkaharju 1988 & 1.02 & 0.04 & ns & -0.055 & 0.057 \\
Stolac 1989 & 0.84 & 0.05 & $* * *$ & +0.110 & 0.148 \\
\hline
\end{tabular}

*** $P<0.001$ 
Table 2 The empty seed percentages in self $(\mathrm{S}), \operatorname{cross}(\mathrm{C})$ and wind pollinations $(\mathrm{W})$, and relative self-fertilities in seven trees in Punkaharju population

\begin{tabular}{|c|c|c|c|c|c|c|c|c|c|c|c|}
\hline \multirow[b]{2}{*}{ Tree } & \multirow[b]{2}{*}{ Year } & \multirow[b]{2}{*}{ Pollination } & \multicolumn{3}{|c|}{$\begin{array}{l}\text { Homogeneity of } \\
\text { cones within } \\
\text { crossings }\end{array}$} & \multirow{2}{*}{$\begin{array}{l}\text { Number } \\
\text { of seeds }\end{array}$} & \multirow{2}{*}{$\begin{array}{l}\text { Empty } \\
\text { seeds } \\
(\%)\end{array}$} & \multicolumn{3}{|c|}{$\begin{array}{l}\text { Difference between } \\
\text { selfing and outcrossing }\end{array}$} & \multirow{2}{*}{$\begin{array}{l}\text { Relative } \\
\text { self-fertility } \\
(R)\end{array}$} \\
\hline & & & $\chi^{2}$ & d.f. & $P$ & & & $t$ & d.f. & $P$ & \\
\hline 1114 & 1988 & $\begin{array}{l}S \\
C \\
W\end{array}$ & $\begin{array}{r}0.43 \\
15.21\end{array}$ & $\begin{array}{l}2 \\
3\end{array}$ & ns & $\begin{array}{l}207 \\
327 \\
395\end{array}$ & $\begin{array}{l}94.2 \\
84.7 \\
96.7\end{array}$ & -0.68 & 5 & ns & 0.38 \\
\hline \multirow[t]{2}{*}{1795} & 1988 & $\begin{array}{l}S \\
C \\
W\end{array}$ & $\begin{array}{l}0.80 \\
0.63\end{array}$ & $\begin{array}{l}3 \\
2\end{array}$ & $\begin{array}{l}\mathrm{ns} \\
\mathrm{ns}\end{array}$ & $\begin{array}{l}368 \\
336 \\
297\end{array}$ & $\begin{array}{l}94.8 \\
80.4 \\
97.6\end{array}$ & -11.60 & 5 & $* * *$ & 0.27 \\
\hline & 1989 & $\begin{array}{l}S \\
C\end{array}$ & $\begin{array}{r}11.68 \\
1.91\end{array}$ & $\begin{array}{l}4 \\
3\end{array}$ & $\begin{array}{l}* \\
\mathrm{~ns}\end{array}$ & $\begin{array}{l}300 \\
275\end{array}$ & $\begin{array}{l}94.3 \\
71.3\end{array}$ & -5.94 & 6 & $* * *$ & 0.20 \\
\hline \multirow[t]{2}{*}{5307} & 1988 & $\begin{array}{l}\mathrm{S} \\
\mathrm{C} \\
\mathrm{W}\end{array}$ & $\begin{array}{r}1.01 \\
99.96\end{array}$ & $\begin{array}{l}3 \\
5\end{array}$ & $\begin{array}{l}\mathrm{ns} \\
* * *\end{array}$ & $\begin{array}{l}346 \\
454 \\
306\end{array}$ & $\begin{array}{l}92.8 \\
68.9 \\
92.8\end{array}$ & 1.32 & 14 & ns & 0.23 \\
\hline & 1989 & $\begin{array}{l}S \\
C\end{array}$ & $\begin{array}{r}12.95 \\
3.12\end{array}$ & $\begin{array}{l}5 \\
4\end{array}$ & $\begin{array}{l}* \\
\mathrm{~ns}\end{array}$ & $\begin{array}{l}296 \\
459\end{array}$ & $\begin{array}{l}95.3 \\
64.5\end{array}$ & -6.94 & 9 & $* * *$ & 0.13 \\
\hline 29 & 1988 & $\begin{array}{l}\mathrm{S} \\
\mathrm{C} \\
\mathrm{W}\end{array}$ & $\begin{array}{l}11.54 \\
29.96\end{array}$ & $\begin{array}{l}2 \\
3\end{array}$ & $\begin{array}{l}* * \\
* * *\end{array}$ & $\begin{array}{r}256 \\
306 \\
64\end{array}$ & $\begin{array}{l}80.9 \\
73.6 \\
93.7\end{array}$ & -0.04 & 5 & ns & 0.72 \\
\hline 24 & 1988 & $\begin{array}{l}\mathrm{S} \\
\mathrm{C} \\
\mathrm{W}\end{array}$ & $\begin{array}{l}57.46 \\
40.54\end{array}$ & $\begin{array}{l}7 \\
7\end{array}$ & $\begin{array}{l}* * * \\
* * *\end{array}$ & $\begin{array}{l}853 \\
760 \\
255\end{array}$ & $\begin{array}{l}78.7 \\
85.4 \\
91.0\end{array}$ & -1.53 & 8 & ns & 1.46 \\
\hline 5308 & 1989 & $\begin{array}{l}S \\
C\end{array}$ & $\begin{array}{l}22.50 \\
23.02\end{array}$ & $\begin{array}{l}9 \\
6\end{array}$ & $\begin{array}{l}* * \\
* * *\end{array}$ & $\begin{array}{l}860 \\
762\end{array}$ & $\begin{array}{l}90.8 \\
88.5\end{array}$ & -1.22 & 15 & ns & 0.8 \\
\hline 41 & 1989 & $\begin{array}{l}\mathrm{S} \\
\mathrm{C}\end{array}$ & $\begin{array}{r}8.12 \\
25.78\end{array}$ & $\begin{array}{l}3 \\
5\end{array}$ & $\begin{array}{l}* \\
* * *\end{array}$ & $\begin{array}{l}284 \\
321\end{array}$ & $\begin{array}{l}33.1 \\
40.5\end{array}$ & 1.17 & 8 & ns & 1.12 \\
\hline
\end{tabular}

${ }^{*} P<0.05,{ }^{* *} P<0.01$ and ${ }^{* * *} P<0.001$.

typically over 0.90 ranging from 0.63 in Thuja occidentalis (Perry \& Knowles, 1990) to 0.99 in Pinus contorta (Epperson \& Allard, 1984). The average of Picea species is 0.88 (Muona, 1989, table 1). The estimates of the outcrossing rates in Punkaharju were approximately 1 in both years.

The genotype frequencies in Punkaharju were consistent with high outcrossing rates. In fact, the fixation indices were slightly negative. A heterozygote deficiency was found in Stolac, which is in accordance with the lower outcrossing rate.

Our data from crossings were heterogeneous but suggested fairly high self-fertility. This conclusion is supported by all earlier available data. Langner (1959) found on average as many full seeds in selfings as in outcrossings in 13 trees, and Koski (1973) stated that the full seed percentages in selfings were as high as in cross pollinations in 12 trees. Selfing in conifers usually leads to a large reduction in seed set: full seed yield after selfing is on average less than half of that after outcrossing, although variation is large among species (see Ledig, 1986, table 2; Charlesworth \& Charlesworth, 1987, table 2).

The high outcrossing rate is unexpected because of the high self-fertility of the species: most conifers studied are thought to depend on early inbreeding depression to eliminate selfs. On the other hand, there is no correlation between self-fertility and the amount of selfing between conifer species (Charlesworth \& Charlesworth, 1987). However, a positive correlation has been found in single trees in Pinus sylvestris (Koski \& Muona, 1986). At the species level the effect of embryonic lethals seems to be obscured by other factors contributing to variation in outcrossing rate. 
Because Serbian spruce is self-fertile but highly outcrossing, it must have a low level of self pollination. Self pollination may be avoided by spatial separation of male and female strobili, as well as protogyny, earlier maturation of female versus male strobili (Stern \& Roche, 1974, pp. 75-77). The influence of the separation of male and female strobili on outcrossing rates is supported by the higher outcrossing rates in the upper parts of the crown than in the lower parts found in some conifers (e.g. Shaw \& Allard, 1982; Omi \& Adams, 1986). Differentiation in the timing of the receptivity of female flowers and pollen shed in the same tree is another way to avoid self-pollination. This is based on the fact that the volume of the pollen chamber is limited and there is room for only the first pollen grains that will then fertilize the eggs. Protogyny has been observed in many conifer species, e.g. in Picea abies (Eriksson et al., 1973) and Pinus sylvestris (Sarvas, 1962). Because of the high self-fertility in Picea omorika, these mechanisms may be responsible for the high outcrossing rate measured in this species. The separation of male and female flowers is more efficient than for example in Picea abies: female strobili are situated in the top of the tree, usually at the end of small twigs, or they grow directly from the stem, and branches carrying male strobili are usually under these. In years of poor flowering, the separation seems to be more pronounced than in good years. On the basis of observations made during the crossings, protogyny also exists in Picea omorika.

In earlier literature, Serbian spruce has been claimed as a selfer because of its high self-fertility. Our data demonstrate that in conifers diverse means have evolved to avoid inbreeding.

\section{Acknowledgements}

We would like to thank the Punkaharju Research Station of Forest Research Institute for help in crossings. We are grateful to Dr A. H. D. Brown and Katri Kärkkäinen for comments on the manuscript. This study was partially supported by grants from the National Research Council for Agriculture and Forestry of the Academy of Finland to Outi Savolainen.

\section{References}

BROWN, A. H. D., BARRETT, S. C. H. AND MORAN, G. F. 1985. Mating system estimation in forest trees: models, methods and meanings. In: Gregorius, H. R. (ed.) Population Genetics in Forestry, Springer-Verlag, Heidelberg, pp. 32-49.

BURSCHEL, P. 1965. Die Omoricafichte. Forstarchiv, 36, 113-131.
CHARLESWORTH, D. AND CHARLESWORTH, B. 1987. Inbreeding depression and its evolutionary consequences. Ann. Rev. Ecol. Syst., 18, 237-268.

EPPERSON, B. K. AND ALLARD, R. W. 1984. Allozyme analysis of the mating system in lodgepole pine populations. $J$. Hered., 75, 212-214.

ERIKSSON, G., JONSSON, A. AND LINDGREN, D. 1973. Flowering in a clone trial of Picea abies Karst. Stud. For. Suec., 110, $1-45$.

GEBUREK, T. H. 1986. Some results of inbreeding depression in Serbian spruce [Picea omorika (Panč.) Purk.]. Silvae Genet., 35, 169-172.

GEBUREK, T. H. AND KRUSCHE, D. 1985. Wachstum von Hybriden zwischen Picea omorika und $P$. sitchensis im Vergleich zu den Elternarten. Allg. Forst. u. J. -Ztg., 156, 47-54.

HEDRICK, P. w. 1987. Genetics of Populations. Jones and Bartlett, London,.

KOSKI, v. 1973. On self-pollination, genetic load and subsequent inbreeding in some conifers. Comm. Inst. For. Fenn., 78. 10, 1-42.

KoSKI, V. AND MUONA, O. 1986. Probability of inbreeding in relation to clonal differences in male flowering and embryonic lethals. Proc. IUFRO Conference on Breeding theory, Progeny Testing and Seed Orchards, Williamsburg, Virginia, pp. 391-400.

KUITTINEN, H., MUONA, O, KÅRKKAINEN, K. AND BORZAN, Ż. 1991. Serbian spruce, a narrow endemic, contains much genetic variation. Can. J. For. Res., 21, 363-367.

LANGNER, w. 1959. Selbstfertilität und Inzucht bei Picea omorica (Pančić) Purkyne. Silvae Genet., 8, 84-93.

LEDIG, F. T. 1986. Heterozygosity, heterosis, and fitness in outbreeding plants. In: Soule, M. E. (ed.) Conservation Biology, The Science of Scarcity and Diversity, Sinauer Association, Sunderland, pp. 77-104.

MUONA, o. 1989. Population genetics in forest tree improvement. In: Brown, A. H. D., Clegg, M. T., Kahler, A. L. and Weir, B. S. (eds) Plant Population Genetics, Breeding and Genetic Resources, Sinauer Association, Sunderland, pp. 285-301.

NEALE, D. B. AND ADAMS, w. T. 1985. The mating system in natural and shelterwood stands of Douglas-fir. Theor. Appl. Genet., 71, 201-207.

Nová, F. R. 1927. Zur fünfzigjährigen Entdeckung der Picea omorica. Mitt. D. D. Ges., 38, 47-56.

OMl, S. K. AND ADAMS, w. T. 1986. Variation in seed set and proportions of outcrossed progeny with clones, crown position and top pruning in a Douglas-fir seed orchard. Can.J. For. Res., 16, 502-507.

PERRY, D. J. AND KNOWLES, P. 1990. Evidence of high selffertilization in natural populations of eastern white cedar (Thuja occidentalis). Can. J. Bot., 68, 663-668.

SARVAS, R. 1962. Investigtions on the flowering and seed crop of Pinus silvestris. Comm. Inst. For. Fenn., 53. 4, 1-192.

SCHEMSKE, D. W. AND LANDE, R. 1985. The evolution of selffertilization and inbreeding depression in plants. II. Empirical observations. Evolution, 39, 41-52.

SEAVEY, R. S. AND BAWA, K. S. 1986. Late-acting selfincompatibility in angiosperms. Bot. Rev., 52, 195-219. 
SHAW, D. V. AND ALLARD, R. w. 1982. Estimation of outcrossing rates in Douglas-fir using isozyme markers. Theor. Appl. Genet., 62, 113-120.

SIMAK, M. 1980. X-radiography in research and testing of forest tree seeds. Reports of Department of Sibuiculturs, Swedish University of Agricultural Sciences, Umea, No 3, pp. 32.

SORENSEN, F. C. 1969. Embryonic genetic load in coastal
Douglas-fir, Pseudotsuga menziesii var. menziesii. Am. Nat., 103, 389-398.

STERN, K. AND ROCHE, L. 1974. Genetics of Forest Ecosystems. Springer-Verlag, Berlin.

WRIGHT, s. 1956. The interpretation of population structure by $F$-statistics with special regard to systems of mating. Evolution, 19, 395-420. 